\title{
Influence of Social Media on Business Education Students' Research Project Work in Universities in Enugu State of Nigeria
}

\author{
Ugwu, Ikenna Vitalis \\ Department of Business Education (Accounting Option) \\ Enugu State University of Science and Technology (ESUT), Enugu State, Nigeria
}

\begin{abstract}
The study was carried out to determine the influence of social media on Business Education students' research project writing in Universities in Enugu State. The study was carried out in public and private universities in Enugu State using a descriptive survey research method. Two research questions and two null hypotheses guided the study. The population for the study comprised 91 Business Education students in three universities offering Business Education in Enugu State during the 2017/2018 academic session. There was no sampling because the population was manageable. The instrument used for data collection was a 17 item structured questionnaire developed by the researcher. The instrument was structured using a four point rating scale and was face validated by three experts, two of them from Business Education Department and one in Measurement and Evaluation from Department of Science and Computer Education both in the Faculty of Education, Enugu State University of Sciences and Technology. Cronbach Alpha was used to determine the reliability of the instrument which gave a value of .84 . The data analysis was based on responses from 87 copies of questionnaire out of 91 copies distributed which represent $95.60 \%$ return rate. Mean and standard deviation were used to answer the research questions and $\mathrm{t}$-test was used to test the hypotheses at .05 level of significance at 94 degree of freedom. The result of the findings showed that communicating with supervisors on the progress of project writing, retrieving of information from friends in other schools, collection of data on the research topic through opinion poll, receiving and sending instrument from validators, sending to and receiving from respondents the questionnaire and its response., receiving appointment days from the supervisor, and giving and receiving research based instructions from the supervisor to the student are some of the positive influences of social media on Business Education students' research work. The null hypotheses tested showed no significant difference in the mean rating of male and female Business Education students on the entire variables. Based on the findings, some implications were deduced and it was recommended among others that the Business Education students should utilize the power of social media in conducting quality empirical studies before they graduate for the propagation of knowledge and business Education students should avoid using social media for academically inglorious activities such as watching of pornographic contents or use of social media to harass, embarrass, impersonate and insult elderly scholars.
\end{abstract}

Keywords: social media, business education, research project, universities.

DOI: $10.7176 / \mathrm{JEP} / 11-12-08$

Publication date: April $30^{\text {th }} 2020$

\section{Introduction}

It is a jet age and social media is fingered as one factor that makes jet age what it is. Social media has been pointed out as a communication technology that has an instant messaging system. Social media according to Bryer and Zavatarro (2011) are technologies that facilitate social interaction, make possible collaboration and enable deliberation across stakeholders. The communication through social media is carried out through the Internet. Social media ensures that friends communicate with ease. It is a computer or handheld device electronically powered online community of individuals (friends) who exchanges messages, share information and in some cases cooperate on joint activities. Osharive (2015) opined that social networking is the use of Internet to make information about one available to other people especially people that share interest with, to send messages to them. Social media technologies have been beneficial to education as most teacher, researchers and students share and obtain relevant information to their discipline.

In the words of Kaplan and Haenkinn (2010), Social media is a group of Internet based applications that are built on the ideological and technological foundation of web 2.0 and allow the creation and exchange of usergenerated content. Social media can also be referred to as relatively inexpensive and widely accessible electronic tools that enable anyone to publish and access information, collaborate on a common effort or build relationship. There is an increasing trend of social media usage by university students to facilitate their learning process. Olutola, Olatoye \& Olatuye (2016) noted that university students use the social media for different reasons which include connecting to their friends for academic purposes, exchange pictures and videos for personal information and so on. Most social networking sites communicate via status message updates and exchange data in text, picture and video forms. A basic social networking software / site allows friends to comment on one authors profiles, send private messages within the network and transfer profiles. Example of prominent social networks are Twitter, whatsApp, Facebook, Instagram, Pinterest, Blackberry, Messenger, Badoo, Linkedin, Myspace, Youtube, Line, 
Skype, Google, Flicker and many others.

Social media and network sites are often thought of as places to catch up on the personal information and current activities. Social networking services (Software and sites) provide a source of information for research that is highly tailored to an individual and comes from a direct source, while the latter provide objective data from variety of sources on a related topics (Meredith, Jaine \& Katriny, 2010). Operating a social network service involves the creation and maintenance of a unique personal account that is linked with other members thus enabling a user to specially connect and communicate with other users that are linked to the specific network through the Internet. Social media enables people to conduct an opinion survey researches that elicit for information from different people in other to take a decision on the subject. Researchers can obtain topics, source for materials, opinions of others, collect data, compare result as well as share information about the research with friends and supervisor(s) via social media.

Research project writing involves a student or group of students carring out a study on a topic of interest in their study areas. According to Thomas (2009), a project is an individual or collaborative enterprise that is carefully planned and researched about by students. Research can be seen as a diligent enquiry or investigation carried out for the purpose of discovering new knowledge. Business Education students are required to conduct an educational research that would improve the body of knowledge in business education. Nworgu (2015) noted that education research is a systematic approach for search for new knowledge, for solution to problems and answers to questions. Alio (2008) defined research in education as a systematic controlled, empirical and critical investigation of hypothetical proposition about the presumed relations among natural phenomena.

A project is a research assignment given to a student which generally requires a larger amount of effort and more independent work than that involved in a normal essay assignment. It requires students to undertake their fact-finding and analysis, either from library and Internet research or from gathering data empirically. The written report that comes from the research project according to Uzoagulu (2011) is usually in the form of project report, dissertation and thesis which will contain sections on the project's inception, analysis, findings and conclusions. The major components of a good research project or report are as follows: the abstract, introduction, methodology, results, discussion and references. For one to have conducted a good project, the report must contain these components. When the project is completed, it is evaluated by the quality of the work submitted within the stipulated time (Fatoki, 2004). It is used to indicate the student's ability to select, research, and draw logical conclusions from findings. The quality of the research project is to a large extent dependent on the quality, quantity, and decency of resources consulted and cited (Mbofung, 2003). The use of the Internet, if maximized, plays a major role in helping undergraduates of tertiary institutions in having access to large number of materials from different parts of the globe. University undergraduates of Business Education programme in Enugu State are not exception to this. Project writing is a major pre-requisite for the award of degrees to University students offering Business Education programme like in other programmes.

Business Education is one of the major components of vocational education. In Nigeria, the discipline is offered at both the secondary and tertiary levels of education. According to Abdullahi (2002), Business Education is an aspect of total educational programme which provides the recipient with knowledge, skills, understanding and attitude needed to perform well in the business world as a producer or consumer of goods and services. Furthermore, Osuala (2004) is of the opinion that Business Education is a broad area of knowledge that deals with a nation's economic system and also identifies and explains the rate of business contentment and experience that prepare individuals for effective participation as citizens, workers and consumers. The National Open University of Nigeria (NOUN 2008) defined Business Education as an aspect of vocational education that equips people with necessary skills and theoretical knowledge needed for performance in business world either for job occupation or self-employment. Osuala (2004) defined Business Education as a programme of instruction which consists of two parts (1) Office education - a vocational programme of office careers through initial, refresher and upgrading education and (2) General Business Education - a programme that provide students with information and competences which are needed by all in managing personal business affairs and in using the services of the business. Still on the definition of business education, Njoku (1997) defined Business Education as that facet of educational training that helps the individual to acquire relevant skills needed for living. However Njoku (2006) gave another definition as an educational programme that equips an individual with functional and suitable skills, knowledge, attitudes and values that would enable them to operate in the environment they find themselves. Business Education is a programme of study which after well taught by professional teachers and well understood by students equips such students with necessary knowledge, attitude, mental alertness and practical skills required for excellent adaption to business and work environment after school. It is based on this very important input of Business Education in the lives of undergraduates that they are mandated to carry out final year project report on their chosen topics. In doing so, the students have the opportunity of exploring all academic resources related to the research topic all around the globe through the use of Internet. 
Statement of the Problem

Social media is a very effective tool in the hands of researchers who know how best to use it for research project works. Most of the gadgets used for social media activities are always relatively reduced in size and handy for easy access by the user. It delivers researchers' intentions faster and more accurately than other means of communication. Business education students utilize this tool as well. Experience has shown that most of these students use their social media handles such as Facebook, WhatsApp, WeChat, Instagram, Line, Twitter, LinkedIn and many more for their social interactions. They use their hand-held gadgets such as mobile phones for this purpose and spend about 3 to 5 hours chatting with their friends; watching and sharing videos and graphic contents of social media. It has been pointed out that if Business Education students utilize the social media platform properly for their research work, quality research project would flood the books' shelves of the offices in Business Education departments of the public universities in Enugu State. The researcher wonders why Business Education students are not producing well researched project works even in the face of social media availability. Does it mean that Business Education students cannot use social media to their advantage in terms of writing quality research projects or that they prefer using it for other social activities? There is need therefore, to determine the influence social media has on Business Education students' research project in the public universities in Enugu State.

\section{Purpose of the Study}

The main purpose of the study is to determine the influence of social media on Business Education students' research projects in the public universities in Enugu State. Specifically, the study sought to determine the:

1. positive influence of social media on Business Education students' research projects in public universities in Enugu State.

2. negative influence of social media on Business Education students' research projects in public universities in Enugu State.

\section{Research Questions}

The following research questions guided the study:

1. What are the positive influences of social media on Business Education students' research projects in public universities in Enugu State?

2. What are the negative influences of social media on Business Education students' research projects in public universities in Enugu State?

\section{Research Hypothesis}

Ho1 There is no significant difference between the mean ratings of male and female respondents on positive influence of social media on Business Education students' research projects in public universities in Enugu State. $\mathbf{H o}_{2}$ There is no significant difference between the mean ratings of male and female respondents on positive influence of social media on Business Education students' research projects in public universities in Enugu State.

\section{Method}

The study adopted a descriptive Survey research design, A survey research design according Anigbo (2010), is a study where the peculiar characters of a population are studied through a sample, which is deemed to be representative of the population. This design was deemed appropriate for the study because the result gotten from the respondents was inferred on the entire population. The population comprised 91 final year students in three universities offering Business Education programme in Enugu State for 2017/2018 academic session which are University of Nigeria, Nsukka, Enugu State University of Science and Technology and Godfrey Okoye University (source: field survey August 2017).

Sampling was not applied because of the manageable size of the population. Instrument used for data collection was an 17 item questionnaire organised by the researcher. Instrument validation was carried out by three experts and Cronbach Alpha was used to determine the reliability of the instrument which yielded 0.86.

The instrument was distributed to the respondents by the researcher, assisted by other two trained research assistants. 91 copies of the questionnaire were distributed to the respondents but 87 of them were filled properly and therefore, used for data analysis as a result. This represents $95.60 \%$ return rate. Mean and standard deviation were used to answer the research questions while in testing the null hypotheses that guided the study, t-test was used. The decision rule was based on the principle of upper and lower limits of the mean thus:

Strongly Agree (SA) 3.50-4.00

Agree

Disagree

$$
\text { (A) } \quad 2.50-3.49
$$

$1.50-2.49$

Strongly Disagree

(SD) $\quad 1.00-1.49$

The decision for the t-test result analysis was: when t-calculated value was more than the critical or t-table 
value, the null hypothesis would be rejected but when the t-test calculated value was less than the table value; the null hypothesis would not be rejected.

Result

The result of the study was presented according to the research questions and null hypotheses that guided the study.

Research Question 1

What are the positive influences of social media on Business Education students' research projects in public universities in Enugu State?

Table 1: Mean ratings and standard deviation of male and Female Business Education Students on the positive influence of using social media/network on Business Education students' research project in universities in Enugu State

\begin{tabular}{|c|c|c|c|c|c|c|c|c|}
\hline \multirow[t]{2}{*}{$\mathbf{S} / \mathbf{N}$} & \multirow[t]{2}{*}{$\begin{array}{l}\text { The positive influence of social media } \\
\text { on research projects includes: }\end{array}$} & \multicolumn{2}{|c|}{$\begin{array}{l}\text { Male } \\
\mathbf{N}=\mathbf{2 9}\end{array}$} & \multicolumn{2}{|c|}{$\begin{array}{c}\text { Female } \\
\mathrm{N}=58\end{array}$} & \multicolumn{2}{|c|}{ Overall } & \multirow[t]{2}{*}{ Decision } \\
\hline & & $\mathbf{X}_{1}$ & SD $_{1}$ & $\bar{X}_{2}$ & $\mathbf{S D}_{2}$ & $\overline{\mathbf{X}}_{\mathbf{G}}$ & $\mathbf{S D}_{\mathrm{G}}$ & \\
\hline 1 & $\begin{array}{l}\text { Communicating with supervisors on the } \\
\text { progress of project writing. }\end{array}$ & 2.91 & 0.66 & 2.79 & 0.77 & 2.84 & 0.73 & Agree \\
\hline 2 & Sourcing for topic through friends/post & 2.92 & 0.65 & 2.81 & 0.74 & 2.85 & 0.71 & Agree \\
\hline 3 & $\begin{array}{l}\text { Sourcing for materials through group } \\
\text { chats and friends }\end{array}$ & 2.80 & 0.58 & 2.76 & 0.73 & 2.77 & 0.68 & Agree \\
\hline 4 & $\begin{array}{l}\text { Retrieving of information from friends in } \\
\text { other schools }\end{array}$ & 2.71 & 0.52 & 2.65 & 0.58 & 2.67 & 0.55 & Agree \\
\hline 5 & $\begin{array}{l}\text { Collection of data on the research topic } \\
\text { through opinion pull }\end{array}$ & 2.74 & 0.56 & 2.63 & 0.68 & 2.67 & 0.64 & Agree \\
\hline 6 & $\begin{array}{l}\text { Receiving and sending instrument from } \\
\text { validators }\end{array}$ & 2.77 & 0.43 & 2.73 & 0.45 & 2.74 & 0.44 & Agree \\
\hline 7 & $\begin{array}{l}\text { Used by students to interact with their } \\
\text { research mates and supervisors about } \\
\text { research procedures }\end{array}$ & 2.91 & 0.61 & 2.89 & 0.66 & 2.90 & 0.64 & Agree \\
\hline 8 & $\begin{array}{l}\text { Sending to and receiving from } \\
\text { respondents the questionnaire and its } \\
\text { response. }\end{array}$ & 2.83 & 0.66 & 2.89 & 0.65 & 2.87 & 0.66 & Agree \\
\hline 9 & $\begin{array}{l}\text { Receiving appointment days from the } \\
\text { supervisor. }\end{array}$ & 2.86 & 0.81 & 2.87 & 0.78 & 2.87 & 0.79 & Agree \\
\hline 10 & $\begin{array}{l}\text { Giving and receiving research based } \\
\text { instructions from the supervisor to the } \\
\text { student. }\end{array}$ & 2.91 & 0.74 & 2.92 & 0.68 & 2.92 & 0.70 & Agree \\
\hline & Cluster mean/SD & 2.84 & 0.62 & 2.79 & 0.67 & 2.81 & 0.65 & Agree \\
\hline
\end{tabular}

The analysis of data presented in Table 1 shows that the overall mean rating of the Business Education students for the 10 items ranging from 2.67 to 2.92 showed agree. The implication was that there is positive influence of social media on Business Education students' research project writing in universities in Enugu State. The overall cluster mean of 2.81 further reveals that the itemized have positive influence on using social media for Business Education students' research projects as it showed agree. The low standard deviation of 0.65 showed that the respondent's opinions do not differ remarkably to the itemized social media influences.

Hypothesis 1

There is no significant difference between the mean ratings of male and female Business Education students on the positive influence of using social media on Business Education students' research projects in Universities in Enugu State

Table 2: t-test analysis of mean rating of male and female Business Education students on the positive influence of using search engines on Business Education students' research projects in Universities in Enugu State

\begin{tabular}{lllccccc}
\hline Variables & $\mathbf{N}$ & t & Df & $\begin{array}{c}\text { Sig. } \\
\text { (2tailed) }\end{array}$ & $\begin{array}{l}\text { Mean } \\
\text { Difference }\end{array}$ & $\begin{array}{l}\text { Std. Error } \\
\text { Difference }\end{array}$ & Decision \\
\hline Male Students & 29 & 0.505 & 85 & 0.615 & 0.45207 & 0.89563 & NS
\end{tabular}

Female $\quad 58$

Students

The result of t-test analysis in Table 2 shows that 48 freedom for the 10 items is .505 with a significant value of 0.615 . Since the significant value of .615 was more 
than the .05 level of significance, the null hypothesis was not significant. This means that there was no significant difference with the regard to the 10 items on the mean rating of male and female Business Education students on the influence of using social media on Business Education students' research projects in Universities in Enugu State.

\section{Research Question 2}

What are the negative influences of social media on Business Education students' research projects in public universities in Enugu State?

Table 3: Mean ratings and standard deviation of Male and Female Business Education students on the negative influences of using social media on Business Education students' research project in Universities in Enugu State

\begin{tabular}{|c|c|c|c|c|c|c|c|c|}
\hline \multirow[t]{2}{*}{$\mathbf{S} / \mathbf{N}$} & \multirow{2}{*}{$\begin{array}{l}\text { The negative influence of using social } \\
\text { media on Business Education } \\
\text { Students' research project includes: }\end{array}$} & \multicolumn{2}{|c|}{$\begin{array}{r}\text { Male } \\
\mathbf{N}=\mathbf{2 9}\end{array}$} & \multicolumn{2}{|c|}{$\begin{array}{c}\text { Female } \\
N=58\end{array}$} & \multicolumn{2}{|c|}{ Overall } & \multirow[t]{2}{*}{ Decision } \\
\hline & & $\overline{\mathbf{X}}_{1}$ & $\mathrm{SD}_{1}$ & $\overline{\mathbf{X}}_{2}$ & $\mathrm{SD}_{2}$ & $\mathbf{X}_{\mathbf{G}}$ & $\mathbf{S D}_{\mathrm{G}}$ & \\
\hline 11 & $\begin{array}{l}\text { Sending of junk messages by students to } \\
\text { supervisors. }\end{array}$ & 3.14 & 0.69 & 3.08 & 0.58 & 3.10 & 0.62 & Agree \\
\hline 12 & $\begin{array}{l}\text { Sending and receiving of mischievous } \\
\text { messages between female students and } \\
\text { male supervisors. }\end{array}$ & 3.29 & 0.52 & 3.21 & 0.58 & 3.24 & 0.55 & Agree \\
\hline 13 & $\begin{array}{l}\text { Watching of pornographic contents by } \\
\text { students }\end{array}$ & 3.03 & 0.62 & 2.84 & 0.75 & 2.91 & 0.71 & Agree \\
\hline 14 & $\begin{array}{l}\text { Excessive use of social media for } \\
\text { chatting purposes. }\end{array}$ & 2.91 & 0.74 & 2.74 & 0.87 & 2.80 & 0.82 & Agree \\
\hline 15 & $\begin{array}{l}\text { Use of social media for fraudulent } \\
\text { purposes by students. }\end{array}$ & 3.06 & 0.76 & 2.71 & 0.79 & 2.84 & 0.80 & Agree \\
\hline 16 & $\begin{array}{l}\text { Posting of irritating contents through } \\
\text { social media to the public by the students. }\end{array}$ & 3.06 & 0.64 & 2.73 & 0.75 & 2.85 & 0.73 & Agree \\
\hline 17 & $\begin{array}{l}\text { Use of social media to harass, embarrass, } \\
\text { impersonate and insult elderly scholars. }\end{array}$ & 2.53 & 0.92 & 2.59 & 0.93 & 2.56 & 0.92 & Agree \\
\hline & Cluster mean/SD & 3.00 & 0.70 & 2.84 & 0.86 & 2.90 & 0.74 & Agree \\
\hline
\end{tabular}

The data presented in Table 3 shows that the overall mean rating obtained for the seven items ranges from 2.80 to 3.10 indicating that the respondents are agreed to the itemized as the negative influences of social media. The agreed responses to all the items showed that the identified seven items are negative influences of social media on Business Education students' research project writing in Universities in Enugu state. An overall cluster mean of 2.90 and cluster standard deviation of 0.74 are obtain for all the items, which is indication that the items are negative influences of using social media on Business Education students' research project in Universities in Enugu state. The relatively low standard deviation value of 0.74 depicts that the respondents did not differ remarkably in their opinions regarding the items.

Hypothesis 2

There is no significant difference between the mean ratings of male and female Business Education students on the negative influence of using social media on Business Education students' research project in universities in Enugu state.

Table 4: t-test analysis of mean rating of male and female Business Education students on the negative influence of using social media on Business Education students' research project in universities in Enugu State

\begin{tabular}{lccccccc}
\hline Variables & $\mathbf{N}$ & & Sig. & $\begin{array}{l}\text { Mean } \\
\text { Difference }\end{array}$ & $\begin{array}{l}\text { Std. Error } \\
\text { Difference }\end{array}$ & Decision \\
\hline $\begin{array}{l}\text { Male } \\
\begin{array}{l}\text { Students } \\
\text { Female }\end{array}\end{array}$ & 29 & 1.705 & 85 & 0.092 & 1.22074 & 0.71613 & NS \\
\end{tabular}

Students

The result of t-test analysis in Table 4 shows that the t-value at 0.05 level of significant and 85 degree of freedom for the seven items is 1.705 with a significant value of 0.092 . Since the significant value of 0.092 is more than the 0.05 level of significant the null hypothesis is not significant. This means that there is no significant difference between the mean ratings of male and female Business Education students on the negative influences of using social media on Business Education students' research project in universities in Enugu State. Hence the null hypothesis is therefore not significant.

\section{Discussion of Findings}

The findings of this study were discussed in line with the responses to the research questions and hypotheses tested 
for the study. The findings of the study according to research question one showed that communicating with supervisors on the progress of project writing, sourcing for topic through friends/post, sourcing for materials through group chats and friends, retrieving of information from friends in other schools, collection of data on the research topic through opinion poll, receiving and sending instrument from validators, used by students to interact with their research mates and supervisors about research procedures, sending to and receiving from respondents the questionnaire and its response., receiving appointment days from the supervisor, and giving and receiving research based instructions from the supervisor to the student were positive influences of social media on Business Education students research projects in universities in Enugu State.

The result of the study indicated that social media helps Business Education students in conducting research project in their university programme. Social media is a good platform for students-researcher and authors in general as it enables easier and faster access to research information. The findings of the study was in agreement with Bell (2013) in Ezeabii, Chibuike \& Udeh (2019) who noted that social media improves students' and teachers' report and motivates students to learn. The findings of the study was factually correct as McBride (2009) noted that social media helps to engage the learners in out of class learning experience.

The findings of the study showed that there is no significant difference between the mean rating of male and female students on the positive influence of social media on Business Education student's research project. This means that gender of the respondents have no influence on their use of social media in research project writing. The findings was supported by Oghenetega and Igere (2014) that gender had no influence on the academic performance of students when using Internet in learning. The implication was that male and female students research project are influenced by social media based on the findings.

In furtherance, findings show that the 7 identified items in research question 2 are negative influences to Business Education students' research project writing in universities in Enugu State. The items identified as negative influences to Business Education students' research project writing include: sending of junk messages by students to supervisors, sending and receiving of mischievous messages between female students and male supervisors, watching of pornographic contents by students, excessive use of social media for chatting purposes., use of social media for fraudulent purposes by students., posting of irritating contents through social media to the public by the students, and Use of social media to harass, embarrass and insult elderly scholars. The entire respondents agreed that all the enumerated items in research question 2 have negative influence on Business Education Student's research project work. The opinions of the respondents was supported by Antony (2016) in Ezeabii et al (2019) as he opined that some students' academics surfer set back as a result of distraction from social media. It was observed in the findings also that there is no significant difference between the mean ratings of male and female Business Education students on the negative influence of using social media on Business Education students' research project in universities in Enugu State.

The findings of the study have a far reaching implication to the lecturers, students and future researchers. The findings of the study have provided enough information on the impact of social media on the project work of the students. The lectures supervising students would understand the place of social media on the students' research project. This would help in guiding the students on the research projects writing using social media in schools.

The findings of the study implied that students should be using the social media for their research works. Another implication is that teachers should encourage the students to be utilizing social media in ensuring that research project is conducted appropriately using the Inte 58 nologies. The findings depicted that utilizing social media for research work by Business Education stur $\lfloor$ surely place them on the zenith of academic and modern research methodologies. The findings have implication for the future researchers and general public. The finding would provide empirical data on the utilization of social media in research project writing. It would also help in providing information on the benefits of social network to research project findings and methodology.

\section{Conclusion}

Social media is a web and application based platform created to enable users share contents and participate in social networking. It enables users to share feelings and ideas including academic ideologies. Students-users of social networks have opportunities of using it for academic purposes; research writing, assignment writing and virtual classroom discussion. It academically enables sourcing of project materials through group chats and friends by students-researchers, retrieving of information from friends in other schools, collection of data on the research topic through opinion poll, receiving and sending instrument from validators, used by students to interact with their research mates and supervisors about research procedures, sending to and receiving from respondents the questionnaire and its response., receiving appointment days from the supervisor, and giving and receiving research based instructions from the supervisor to the student. As good and positively effective as social network stands to represent in the society, if misused can pose serious threat to students' academic excellence and ability to conduct robust research work. The onus is therefore, on the students to make appropriate use of social media facilities to achieve academic excellence. 


\section{Recommendations}

Based on the findings of the study, the following recommendations were made:

1. Business Education students should utilize the power of social media in conducting quality empirical studies before they graduate for the propagation of knowledge.

2. Business Education students should avoid using social media for academically inglorious activities such as watching of pornographic contents or use of social media to harass, embarrass, impersonate and insult elderly scholars

\section{References}

Abdullahi, A. (2002). Business education, technology and national development. Book of reading in Business education, 1 (2), 1-5.

Alio, A. N. (2008). Fundamentals of Educational Research. Enugu. Samireen Nigeria Ltd.

Anigbo L.C. (2010). Foundation of Research in Education. Enugu: Providence Press Nig. Ltd.

Bryer, T. \& Zavattaro, S. (2011). Social media and public administration: Theoretical dimensions and introduction to symposium. Administrative Theory \& Praxis, 333, 325-340.

Ezeabii I.C., Chibuike V.C., Udeh S.O. (2016). Influence of Social Media on Academic Performance of Business Education Students of Public Universities In Southeast States of Nigeria. British Journal of Education, 7, 8190.

Fatoki, O.C. (2004). Influence of library resources and the Internet on undergraduate students research, University of Ibadan, Nigeria. Nigerian Libraries, 381, 21-33.

Kaplan, A.M. and Haenlein, M. (2010), "Users of the world, unite! The challenges and opportunities of social media". Business Horizons, 53, 59-68.

Mbofong, U.I. (2003). Students' project write-up in the polytechnic: Issues arising. Part 1 Nigeria Library and Information Science Review, 18, 7-17.

McBride, K. (2009). Social-networking sites in foreign language classes: Opportunities for recreation. The next generation: Social networking and online collaboration in foreign language learning, 35-58.

National Open University of Nigeria (2008). Business Education methods. Lagos: National Open University of Nigeria.

Njoku, C.U. (1997). An Appraisal of Business Education Programme in Selected Tertiary Institutions in Nigeria Unpublished. Ph.D Thesis. University of Nigeria Nsukka.

Njoku, C.U. (2006). Business Education and Value Orientation for National Economic Empowerment and Development. Paper presented at the Owo. 2006 Annual Conference of the Association of Business Education of Nigeria $(A B E N)$.

Nworgu, B.G. (2015). Educational Research; Basic issues and methodology. Nsukka; University Trust Publishers.

Oghenetega I. \& Igere M.A. (2014). Impact of the Internet on academic performance of students in tertiary institution in Nigeria. Journal of information and knowledge management, 5, 3-4.

Olutola, .A.T, Olatoye, O.O \& Olatoye, R.A (2016). Assessment of Social Media Utilization and Study Habit of Students of Tertiary Institutions in Katsina State. Journal of Education and Practice 7, 178-188.

Oshariv, P. (2015). Social media and academic performance of students, conference paper of January 2015. Retrieved 1 April, 2020 from https://www.researchgate.net/ publication/273765340.

Osuala, E.C. (2004). Foundation of vocational education $\left(5^{\text {th }} \mathrm{ed}\right)$.Enugu: Cheston Agency Ltd.

Osuala, E.C., (2004). Principles and Methods of Business and Computer Education, Enugu, Cheston Agency Ltd. Thomas, G. (2009). How to do your research project. Sage Publications Incorporated.

Uzoagulu, A.E. (2011). Practical Guide to Writing Research Report in Tertiary Institutions. Enugu; John Jacobs Classic Publishers Ltd. 